УДК $330.1+338.3$

DOI: https://doi.org/10.37320/2415-3583/15.12

Товмасян B.P.

кандидат економічних наук, докторант ПВНЗ «Європейський університет» ORCID: https://orcid.org/0000-0002-1802-8939

\title{
МЕТОДИ ВИЗНАЧЕННЯ РІВНЯ ЕФЕКТИВНОСТІ ФІНАНСОВОЇ ПОЛІТИКИ ПІДПРИЕМСТВ АВІАЦІЙНОЇ ПРОМИСЛОВОСТІ
}

У статті представлено результати аналізу та оиінки ефективності фінансової політики підприємств на основі розробленого методичного підходу. Запропоновано визначати ефективність фінансової політики підприємства за нерівністю, відповідно до якої фінансова стійкість має перевищувати відтворюваність фінансових ресурсів, яка повинна перевищувати гнучкість власних вкладень у розвиток підприємства, щзо має перевищувати достатність фінансових ресурсів на незаплановані витрати. Відповідно до запропонованого методичного підходу до оцінювання ефективності фінансової політики здійснено ї̈ аналіз за групою досліджуваних підприємств авіачійної промисловості України з виведенням узагальнених результатів для зрізу підприємств досліджуваної промисловості. Проведено комплексне оцінювання показників ефективності фінансової політики ДП «Антонов», ТОВ «Київаеропроєкт», ДП Конотопський авіаремонтний завод "Авіакон», ДП «Львівський державний авіаиійно-ремонтний завод», ДП «Харківський машинобудівний завод (ФЕД)» та ПАТ «Мотор Січ». Застосовано відповідні визначеним критеріальним ознакам інтегральні показники, які спрямовані на визначення відхилення сумарної величини ефективності регулюючих та оптимізуючих фінансових інструментів, щзо даватиме змогу визначати рівень покрашення стану підприємства. Запропоновано методичний підхід до визначення ефективності фінансової політики на основі використання ієрархічної моделі побудови інтегрального показника, яка вмішує базові індикатори, а саме показники динаміки за об 'єктами фінансової політики. Визначено, щзо для підвищення ефективності фінансової політики авіаційних підприємств на об'єкти фінансової політики слід спрямовувати регулюючі та оптимізаційні інструменти, які підвищуватимуть ї̈ рівень за критеріями «оборотність» та «стійкість». 3'ясовано, щзо запропонований науково-методичний підхід до оцінювання економічних результатів ефективності фінансової політики підприсмств авіаційної промисловості дасть змогу визначати ї̈ стан та коригувати систему прийняття рішень иляхом модернізації системоутворюючих елементів управлінського та економічного впливу на інновачійні процеси в посткризовий період.

Ключові слова: фінанси, фінансово-економічні відносини, фінансовий менеджмент, критерії оцінювання фінансової політики, фінансові показники, фінансовий аналіз. 
Постановка проблеми. Забезпечення ефективної фінансової політики підприємств авіаційної промисловості як драйверів імплементації новітніх технологій, бюджетоутворюючих стратегічних підприємств є важливою задачею управління сучасною виробничоекономічною системою за одночасного збереження їх фінансової незалежності. У зв'язку з цим доцільним є проведення діагностики рівня ефективності фінансової політики підприємств авіаційної промисловості за динамікою їх зміни з використанням показників приросту чи падіння ключових економічних показників за об'єктами фінансової політики. Така діагностика дає змогу визначити тенденції та виокремити ті об'єкти, які потребують вжиття певних специфічних певних заходів координування. Це обумовлює потребу застосування комплексного системного методичного підходу до оцінювання ефективності фінансової політики підприємств.

Аналіз останніх досліджень і публікацій. Методичні положення та практичні аспекти проведення аналізу та оцінювання фінансового стану підприємств, показників їх фінансової діяльності, фінансової стійкості досліджено в наукових працях багатьох вітчизняних та зарубіжних учених. Потрібно відзначити наукові праці А.М. Сріної, С.С. Ващаєва [7], В.В. Ковальова [9], Р.С. Хігінса [10]. Вченими запропоновано методи оцінювання фінансового стану підприємств, фінансових показників, аналізу ризиків. Водночас залишається потреба розроблення комплексної системи діагностики ефективності фінансової політики підприємств.

Мета статті полягає у проведенні діагностики ефективності фінансової політики підприємств авіаційної промисловості на основі розробленої сучасної уніфікованої системи інтегральних показників оцінювання.

Виклад основного матеріалу. Ефективність фінансової політики авіаційних підприємств залежить від вжиття заходів, які сприяють зростанню економічної динаміки. Ефективність фінансової політики підприємства пропонується визначати за нерівністю, відповідно до якої фінансова стійкість має перевищувати відтворюваність фінансових ресурсів, яка повинна перевищувати гнучкість власних вкладень у розвиток підприємства, що має перевищувати достатність фінансових ресурсів на незаплановані витрати. Відповідно до запропонованого методичного підходу до оцінювання ефективності фінансової політики здійснимо iii аналіз за групою досліджуваних підприємств авіаційної промисловості України з виведенням узагальнених результатів для зрізу підприємств досліджуваної промисловості.

Досліджувані розрізи фінансової політики за індикаторами регулюючого та оптимізуючого комплексу фінансових інструментів мали на меті визначити певну спрямованість фінансової політики, результати якої приводять або не приводять до розвитку підприємства за його фінансовими показниками. Проте загалом оцінювати ефективність фінансової політики варто за узагальненням обох напрямів. При цьому за міру ефективності варто взяти відхилення сумарної величини ефективності регулюючих та оптимізуючих фінансових інструментів від центральних значень, визначених на основі медіани. На основі такого відхилення $\epsilon$ можливість виявити ефективність як перевагу над середньостатистичним значенням, а надалі на основі

Таблиця 1 - Інтерпретаційна карта інтегральних показників ефективності фінансової політики ТОВ «Київаеропроскт»

\begin{tabular}{|c|c|c|c|c|c|c|c|c|}
\hline \multirow{3}{*}{$\begin{array}{c}\text { Облікові } \\
\text { періоди }\end{array}$} & \multicolumn{7}{|c|}{ Критеріальні ознаки } & \multirow{3}{*}{$\begin{array}{c}\text { Стан фінансової політики } \\
\text { ка безперебійна діяльність }(S B)\end{array}$} \\
\hline & \multicolumn{2}{|c|}{$\begin{array}{l}\text { Стійкість } \\
\text { (EDF) }\end{array}$} & \multicolumn{2}{|c|}{$\begin{array}{l}\text { Оборотність } \\
\text { (EVF) }\end{array}$} & \multicolumn{2}{|c|}{$\begin{array}{l}\text { Маневреність } \\
\text { (EGF) }\end{array}$} & \multirow{2}{*}{$\begin{array}{c}\begin{array}{c}\text { Іммобілізація } \\
\text { (EDA) }\end{array} \\
-0,17\end{array}$} & \\
\hline & 0,75 & $>$ & 0,10 & $>$ & $-0,10$ & $>$ & & \\
\hline 2016 & 9,00 & $>$ & 9,12 & $>$ & 0,25 & $>$ & $-0,82$ & Стійка безперебійна діяльність $(S B)$ \\
\hline 2017 & 1,38 & $>$ & $-0,52$ & $<$ & 0,50 & $>$ & 0,33 & Дестабілізація ділової активності $(D M)$ \\
\hline 2018 & 0,17 & $<$ & 0,24 & $>$ & $-0,05$ & $=$ & $-0,05$ & Дестабілізація стійкості $(D D)$ \\
\hline 2019 & 32,02 & $>$ & 1,96 & $<$ & 2,36 & $>$ & 1,22 & Дестабілізація ділової активності (DM) \\
\hline $\begin{array}{c}\text { Інтегральний } \\
\text { показник }\end{array}$ & 8,66 & $>$ & 2,18 & $>$ & 0,59 & $>$ & 0,10 & Стійка безперебійна діяльність (SB) \\
\hline
\end{tabular}

Джерело: розраховано та складено автором

Таблиця 2 - Інтерпретаційна карта інтегральних показників ефективності фінансової політики ДП «Антонов»

\begin{tabular}{|c|c|c|c|c|c|c|c|c|}
\hline \multirow{3}{*}{$\begin{array}{c}\text { Облікові періоди } \\
2015\end{array}$} & \multicolumn{7}{|c|}{ Критеріальні ознаки } & \multirow{3}{*}{\begin{tabular}{|l|} 
Стан фінансової політики \\
Антикризова активність $(K)$
\end{tabular}} \\
\hline & \multicolumn{2}{|c|}{$\begin{array}{c}\text { Стійкість } \\
(E D F)\end{array}$} & \multicolumn{2}{|c|}{$\begin{array}{l}\text { Оборотність } \\
(E V F)\end{array}$} & \multicolumn{2}{|c|}{$\begin{array}{c}\text { Маневреність } \\
(E G F)\end{array}$} & \multirow{2}{*}{\begin{tabular}{c|}
$\begin{array}{c}\text { Іммобілізація } \\
(\boldsymbol{E D} \boldsymbol{A})\end{array}$ \\
$-0,08$ \\
\end{tabular}} & \\
\hline & $-0,75$ & $<$ & 0,07 & $<$ & 0,11 & $>$ & & \\
\hline 2016 & $-44,82$ & $<$ & $-0,78$ & $<$ & $-0,43$ & $>$ & $-0,66$ & Антикризова активність $(K)$ \\
\hline 2017 & 1,76 & $<$ & 2,07 & $<$ & 2,82 & $>$ & 2,55 & Антикризова активність $(K)$ \\
\hline 2018 & 1,92 & $>$ & 0,29 & $<$ & 0,36 & $>$ & $-0,07$ & $\begin{array}{l}\text { Дестабілізація ділової } \\
\text { активності }(D M)\end{array}$ \\
\hline 2019 & $-6,18$ & $<$ & $-0,54$ & $<$ & 1,47 & $>$ & 0,41 & Антикризова активність $(K)$ \\
\hline $\begin{array}{c}\text { Інтегральний } \\
\text { показник }\end{array}$ & $-9,61$ & $<$ & 0,22 & $<$ & 0,86 & $>$ & $\mathbf{0 , 4 3}$ & Антикризова активність (K) \\
\hline
\end{tabular}

Джерело: розраховано та складено автором [1] 
Таблиця 3 - Інтерпретаційна карта інтегральних показників ефективності фінансової політики ДП Конотопський авіаремонтний завод «Авіакон»

\begin{tabular}{|c|c|c|c|c|c|c|c|c|}
\hline \multirow{3}{*}{$\begin{array}{c}\text { Облікові } \\
\text { періоди }\end{array}$} & \multicolumn{7}{|c|}{ Критеріальні ознаки } & \multirow{3}{*}{$\begin{array}{c}\text { Стан фінансової політики } \\
\text { абілізація ділової активності }(D M)\end{array}$} \\
\hline & \multicolumn{2}{|c|}{$\begin{array}{c}\text { Стійкість } \\
(E D F)\end{array}$} & \multicolumn{2}{|c|}{$\begin{array}{c}\text { Оборотність } \\
(E V F)\end{array}$} & \multicolumn{2}{|c|}{$\begin{array}{c}\text { Маневреність } \\
(E G F)\end{array}$} & \multirow{2}{*}{\begin{tabular}{|c|}
$\begin{array}{c}\text { Іммобілізація } \\
(\boldsymbol{E D} \boldsymbol{A})\end{array}$ \\
$-0,14$ \\
\end{tabular}} & \\
\hline & 0,06 & $>$ & $-0,24$ & $<$ & 0,20 & $>$ & & \\
\hline 2016 & 0,40 & $>$ & 0,37 & $>$ & $-0,35$ & $<$ & 0,19 & Дестабілізаційна активність $(D A)$ \\
\hline 2017 & $-0,13$ & $>$ & $-0,51$ & $<$ & 0,14 & $>$ & $-0,24$ & Дестабілізація ділової активності (DM) \\
\hline 2018 & 0,38 & $>$ & $-0,18$ & $<$ & 0,06 & $>$ & 0,03 & Дестабілізація ділової активності $(D M)$ \\
\hline 2019 & 0,01 & $>$ & $-0,62$ & $<$ & 3,01 & $>$ & 1,71 & Дестабілізація ділової активності (DM) \\
\hline $\begin{array}{c}\text { Інтегральний } \\
\text { показник }\end{array}$ & 0,14 & $>$ & $-0,24$ & $<$ & 0,61 & $>$ & $\mathbf{0 , 3 1}$ & Дестабілізація ділової активності (DM) \\
\hline
\end{tabular}

Джсерело: розраховано та складено автором [2]

Таблиця 4 - Інтерпретаційна карта інтегральних показників ефективності фінансової політики ДП «Львівський державний авіаційно-ремонтний завод»

\begin{tabular}{|c|c|c|c|c|c|c|c|c|}
\hline \multirow{3}{*}{$\begin{array}{c}\text { Облікові } \\
\text { періоди }\end{array}$} & \multicolumn{7}{|c|}{ Критеріальні ознаки } & \multirow{3}{*}{\begin{tabular}{|l|}
\multicolumn{1}{|c}{ Стан фінансової політики } \\
$\begin{array}{l}\text { Дестабілізація ділової } \\
\text { активності }(D M)\end{array}$
\end{tabular}} \\
\hline & \multicolumn{2}{|c|}{$\begin{array}{l}\text { Стійкість } \\
(E D F)\end{array}$} & \multicolumn{2}{|c|}{ Оборотність $(E V F)$} & \multicolumn{2}{|c|}{$\begin{array}{l}\text { Маневреність } \\
(E G F)\end{array}$} & \multirow{2}{*}{$\begin{array}{c}\begin{array}{c}\text { Іммобілізація } \\
(\boldsymbol{E D} \boldsymbol{A})\end{array} \\
-0,44\end{array}$} & \\
\hline & $-0,59$ & $>$ & $-0,70$ & $<$ & $-0,32$ & $>$ & & \\
\hline 2016 & 0,70 & $<$ & 13,14 & $>$ & 0,56 & $<$ & 0,67 & Дисантисипація діяльності $(A)$ \\
\hline 2017 & $-0,06$ & $<$ & 5,22 & $>$ & $-0,48$ & $<$ & $-0,45$ & Дисантисипація діяльності $(A)$ \\
\hline 2018 & 0,60 & $>$ & 0,15 & $<$ & 2,28 & $>$ & 0,20 & $\begin{array}{l}\text { Дестабілізація ділової } \\
\text { активності }(D M)\end{array}$ \\
\hline 2019 & $-0,13$ & $<$ & 0,45 & $>$ & $-0,26$ & $<$ & 0,30 & Дисантисипація діяльності $(A)$ \\
\hline $\begin{array}{c}\text { Інтегральний } \\
\text { показник }\end{array}$ & 0,1 & $<$ & 3,65 & $>$ & 0,36 & $>$ & 0,06 & Дестабілізація стійкості (DD) \\
\hline
\end{tabular}

Джерело: розраховано та складено автором [3]

Таблиця 5 - Інтерпретаційна карта інтегральних показників ефективності фінансової політики ДП «Харківський машинобудівний завод (ФЕД)»

\begin{tabular}{|c|c|c|c|c|c|c|c|c|}
\hline \multirow{3}{*}{$\begin{array}{c}\text { Облікові } \\
\text { періоди }\end{array}$} & \multicolumn{7}{|c|}{ Критеріальні ознаки } & \multirow{3}{*}{$\begin{array}{c}\text { Стан фінансової політики } \\
\text { Криза надфінансування }(Z)\end{array}$} \\
\hline & \multicolumn{2}{|c|}{$\begin{array}{l}\text { Стійкість } \\
(E D F)\end{array}$} & \multicolumn{2}{|c|}{ Оборотність $(E V F)$} & \multicolumn{2}{|c|}{$\begin{array}{c}\text { Маневреність } \\
(E G F)\end{array}$} & \multirow{2}{*}{$\begin{array}{c}\begin{array}{c}\text { Іммобілізація } \\
(\boldsymbol{E D} \boldsymbol{A})\end{array} \\
0,94\end{array}$} & \\
\hline & 5,20 & $>$ & $-0,53$ & $<$ & 0,90 & $<$ & & \\
\hline 2016 & 1,36 & $>$ & $-0,56$ & $<$ & $-0,37$ & $<$ & 0,36 & Криза надфінансування $(Z)$ \\
\hline 2017 & $-0,73$ & $<$ & 0,61 & $<$ & 2,80 & $>$ & 0,18 & Антикризова активність $(K)$ \\
\hline 2018 & $-0,44$ & $<$ & 0,17 & $<$ & 0,82 & $>$ & 0,20 & Антикризова активність $(K)$ \\
\hline 2019 & 0,19 & $<$ & 0,56 & $>$ & $-0,44$ & $<$ & 0,05 & Дисантисипація діяльності $(A)$ \\
\hline $\begin{array}{c}\text { Інтегральний } \\
\text { показник }\end{array}$ & 1,12 & $>$ & 0,05 & $<$ & 0,74 & $>$ & 0,35 & $\begin{array}{l}\text { Дестабілізація ділової } \\
\text { активності }(D M)\end{array}$ \\
\hline
\end{tabular}

Джерело: розраховано та складено автором [4]

Таблиця 6 - Інтерпретаційна карта інтегральних показників ефективності фінансової політики ПАТ «Мотор Січ»

\begin{tabular}{|c|c|c|c|c|c|c|c|c|}
\hline \multirow{3}{*}{$\begin{array}{r}\text { Облікові } \\
\text { періоди } \\
2015\end{array}$} & \multicolumn{7}{|c|}{ Критеріальні ознаки } & \multirow{3}{*}{\begin{tabular}{|l|} 
Стан фінансової політики \\
Криза надфінансування $(Z)$ \\
\end{tabular}} \\
\hline & \multicolumn{2}{|c|}{$\begin{array}{l}\text { Стійкість } \\
(E D F)\end{array}$} & \multicolumn{2}{|c|}{$\begin{array}{l}\text { Оборотність } \\
(E V F)\end{array}$} & \multicolumn{2}{|c|}{$\begin{array}{l}\text { Маневреність } \\
(E G F)\end{array}$} & \multirow{2}{*}{\begin{tabular}{|c|}
$\begin{array}{l}\text { Іммобілізація } \\
(\boldsymbol{E D} \boldsymbol{A})\end{array}$ \\
2,73 \\
\end{tabular}} & \\
\hline & 8,00 & $>$ & 0,75 & $<$ & 0,97 & $<$ & & \\
\hline 2016 & $-0,31$ & $<$ & 1,06 & $<$ & 1,92 & $>$ & 0,16 & Антикризова активність $(K)$ \\
\hline 2017 & 0,73 & $>$ & 0,13 & $>$ & $-0,08$ & $<$ & 0,48 & Дестабілізаційна активність $(D A)$ \\
\hline 2018 & 2,29 & $>$ & $-0,60$ & $<$ & 2,16 & $>$ & $-0,06$ & Дестабілізація ділової активності (DM) \\
\hline 2019 & 5,38 & $>$ & $-0,78$ & $<$ & 4,36 & $>$ & 0,58 & Дестабілізація ділової активності (DM) \\
\hline $\begin{array}{c}\text { Інтегральний } \\
\text { показник }\end{array}$ & 3,22 & $>$ & $\mathbf{0 , 1 1}$ & $<$ & 1,86 & $>$ & $\mathbf{0 , 7 8}$ & Дестабілізація ділової активності (DM) \\
\hline
\end{tabular}

Досерело: розраховано та складено автором [5] 


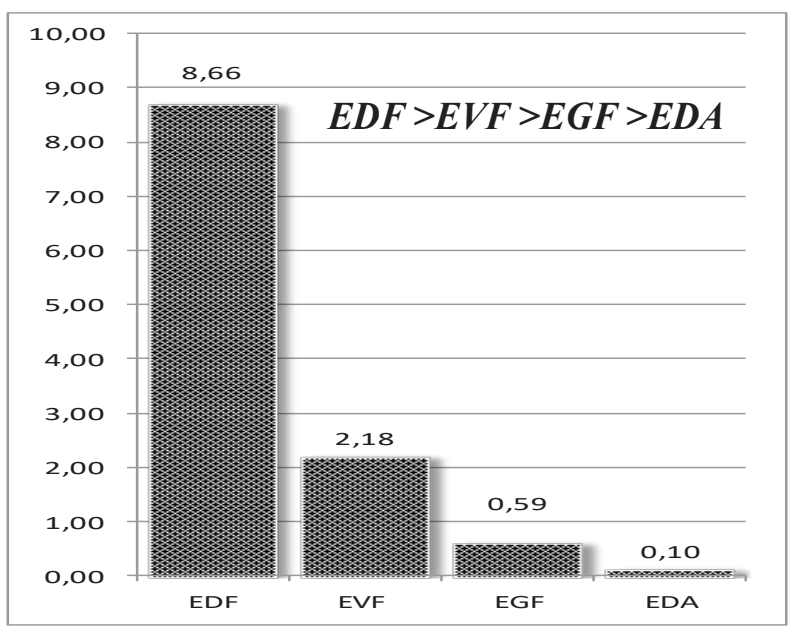

а) стійка безперебійна діяльність

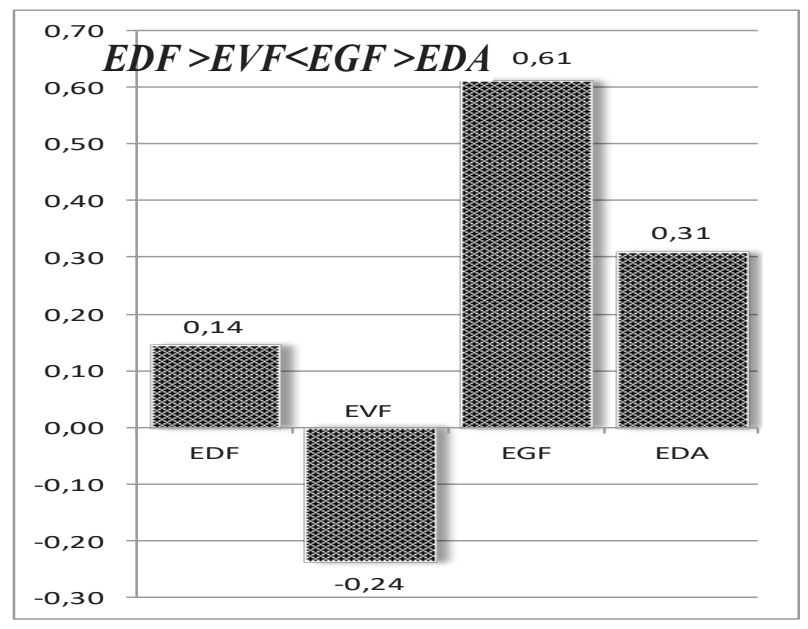

в) дестабілізація ділової активності

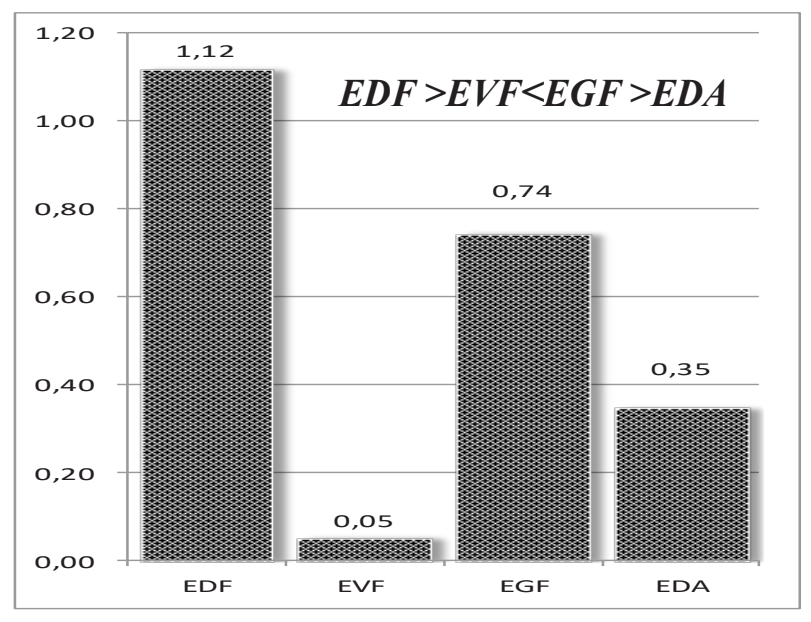

д) дестабілізаџія ділової активності

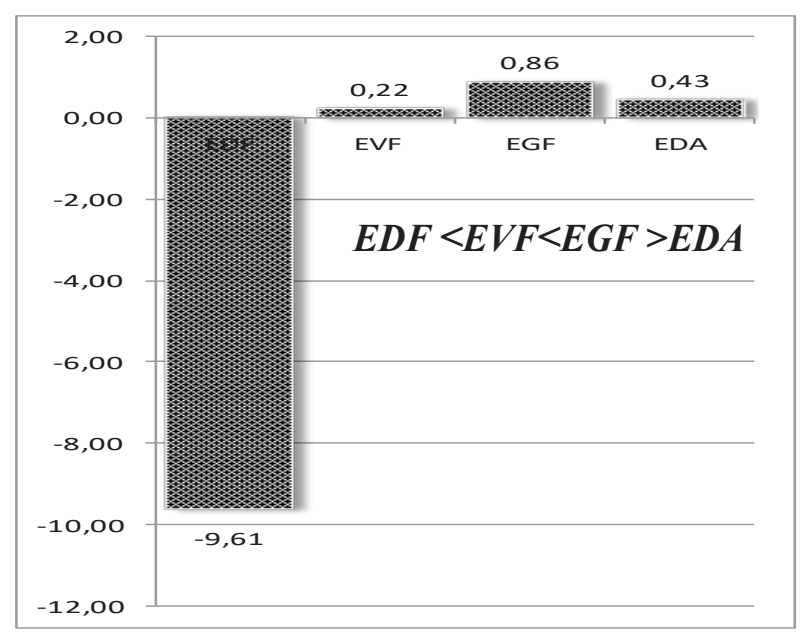

б) антикризова активність

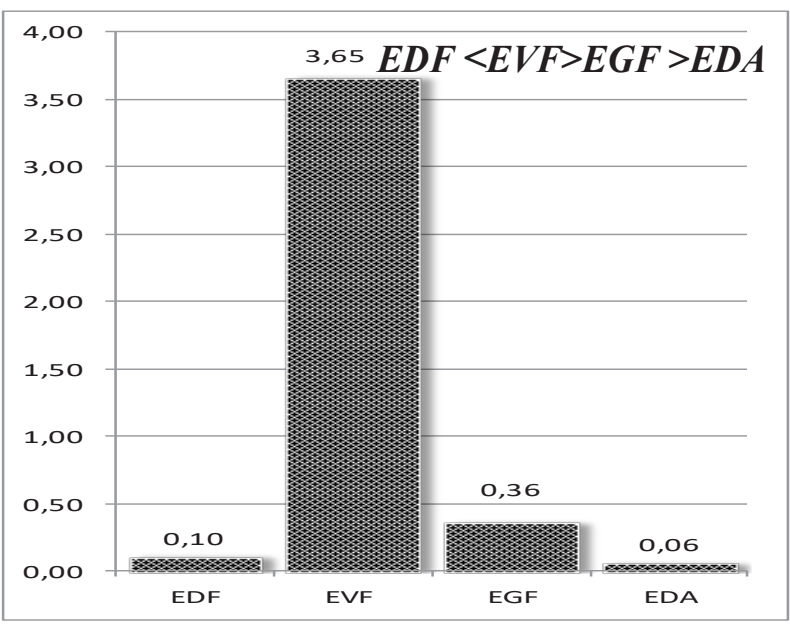

г) дестабілізаичія стійкості

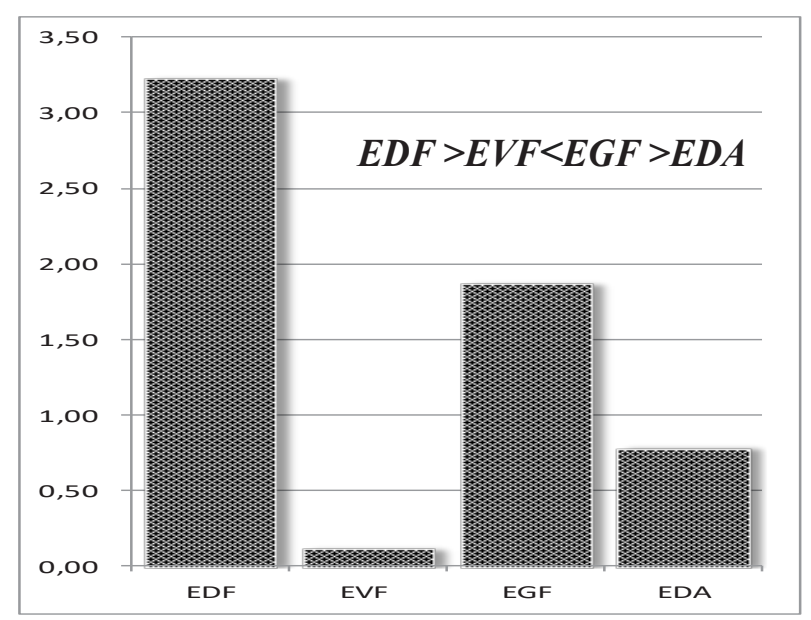

е) дестабілізаџія ділової активності

Рисунок 1 - Графічна інтерпретація інтегрального показника ефективності фінансової політики авіаційних підприємств за 2015-2019 рр. ТОВ «Київаеропроєкт» (а), ДП «Антонов» (б), ДП Конотопський авіаремонтний завод «Авіакон» (в), ДП «Львівський державний авіаційно-ремонтний завод» (г), ДП «Харківський машинобудівний завод (ФЕД)» (д), ПАТ «Мотор Січ» (е) 
проведених розрахунків виявити загальний стан підприємств згідно з фінансовою політикою.

Наступним кроком $€$ визначення інтегрального показника ефективності фінансової політки підприємств шляхом розрахунку середнього гармонійного періоду дослідження у п'ять років.

ТОВ «Київаеропроєкт» за 2015-2019 рр. мало змінний рівень ефективності фінансової політики (табл. 1), проте більшість визначилась на рівні стійкої безперебійної діяльності, що, зрештою, за інтегральним показником за п'ять років вивело підприємство на відповідність досліджуваній нерівності. Загалом функції забезпечення наступності та інновацій у фінансовій політиці підприємства виконуються.

Фінансова політика ДП «Антонов» переважно за іiі ефективністю протягом досліджуваного періоду була спрямована на антикризову активність, що, зрештою, визначило її як таку за рівнем ефективності (табл. 2).

Для підприємства ДП Конотопський авіаремонтний завод «Авіакон» в узагальненому випадку ефективність фінансової політики виражається станом дестабілізації ділової активності (табл. 3). При цьому систематично порушуються іiї аналітично-прогностична та стабілізаційна функції.

Фінансова політика ДП «Львівський державний авіаційно-ремонтний завод» характеризувалася змінністю станів «дестабілізація ділової активності» та «дисантисипація діяльності», що, зрештою, визначало iii ефективність як дестабілізацію стійкості (табл. 4). Відбувається порушення функцій фінансової політики, а саме забезпечення наступності та нормуючої функції.

Фінансова політка ДП «Харківський машинобудівний завод (ФЕД)» визначається певними турбулентними подіями, що не дає змоги підприємству постійно розвиватись. Регулярна зміна стану ефективності протягом 2015-2019 рр., зрештою, дає змогу все ж таки вважати політику підприємства такою, що перебуває на рівні дестабілізації ділової активності (табл. 5). Це призводить до порушення іiі аналітично-прогностичної та стабілізаційної функцій.

Для підприємства ПАТ «Мотор Січ» події, що стались останніми роками, призвели до стану дестабілізації ділової активності, закріплюючи це положення за ефективністю фінансової політики і загалом за 2015-2019 рр. (табл. 6).
Загалом, як наведено на рис. 1, ефективність фінансової політики досліджуваних підприємств має недостатньо ефективний стан, у якому переважає дестабілізація як ділової активності, так і стійкості, яка на окремих підприємствах переходить в антикризову активність. Це свідчить про те, що застосовуваний комплекс регулюючих та оптимізаційних фінансових інструментів $\epsilon$ недостатньо ефективним для забезпечення відповідної нерівності, згідно з якою:

- зростання оборотності, тобто відтворення фінансових ресурсів, має перевищувати маневреність, тобто гнучкість власних вкладень;

- зростання стійкості, а саме динамічної фінансової стійкості, має перевищувати зростання оборотності, тобто відтворення фінансових ресурсів.

Таким чином, для підвищення ефективності фінансової політики авіаційних підприємств на об'єкти фінансової політики слід спрямовувати регулюючі та оптимізаційні інструменти, які підвищуватимуть іiі рівень за критеріями «оборотність» та «стійкість».

Висновки. Результати проведеної діагностики фінансової політики підприємств авіаційної промисловості свідчать про те, що за критерієм «стійкість» фінансову політику досліджуваних підприємств авіаційної промисловості не можна назвати довгостроковою та орієнтованою на перспективу. Швидше за все, вона спрямована на утримання ринкових позицій та забезпечення функціонування підприємства на відносно стабільному рівні. Крім того, з розвитком новітніх технологій у світовій авіаційній індустрії та порівняно з нею низькими темпами розробок, які продукує вітчизняний високотехнологічний авіаційний сектор, нематеріальні активи за критерієм оборотності залишаються сталими. Це в подальшому може привести до необхідності кардинальної різкої зміни наявних об'єктів інтелектуальної власності. За таких обставин вимагає нових підходів амортизаційна політика.

3'ясовано, що діагностика ефективності фінансової політики підприємства має бути спрямована на два комплекси інструментів, а саме регулюючий та оптимізаційний, які підвищуватимуть ії рівень за критеріями «оборотність» та «стійкість». Перспективними напрямами досліджень $є$ розроблення механізмів модернізації фінансової політики підприємств авіаційної промисловості.

\section{Список використаних джерел:}

1. ДП «Антонов». URL: https://www.antonov.com (дата звернення: 20.11.2020).

2. ДП Конотопський авіаремонтний завод «Авіакон». URL: https://www.aviakon.com (дата звернення: 20.11.2020).

3. ДП «Львівський державний авіаційно-ремонтний завод». URL: http://sarp.com.ua (дата звернення: 20.11.2020).

4. ДП «Харківський машинобудівний завод (ФЕД)». URL: https://fed.ua/ru/pro-pidpryyemstvo (дата звернення: 20.11.2020).

5. ПАТ «Мотор Січ». URL: http://www.motorsich.com/ukr (дата звернення: 20.11.2020).

6. Нормирование показателей. Подготовка и обработка, анализ и представление данных. URL: https://psytest.wordpress.com/ data_treatment/normalization_indicator (дата звернення: 20.11.2020).

7. Єріна А.М., Ващаєв С.С. Узагальнюючі багатовимірні показники в соціально-економічних дослідженнях. Наукові записки Києво-Могилянської академії. Економіка. 1999. Т. 6. С. 38-41.

8. Оцінка корпоративного управління державним авіаційним сектором України. Приклад ДП «Антонов». OECED. 2012. URL: https://www.oecd.org/eurasia/competitiveness-programme/eastern-partners/AntonovUK.pdf (дата звернення: 20.11.2020).

9. Ковалев В.В. Финансовый анализ: методы и процедуры. Москва : Финансы и статистика, 2002. 560 с.

10. Хиггинс Р.С. Финансовый анализ: инструменты для принятия бизнес-решений. Москва : ООО «И.Д. Вильямс», 2007. 164 с.

\section{References:}

1. DP “Antonov". Available at: https://www.antonov.com (accessed 20 November 2020).

2. DP Konotopskyi aviaremontnyi zavod “Aviakon”. Available at: https://www.aviakon.com (accessed 20 November 2020). 
3. DP "Lvivskyi derzhavnyi aviatsiino-remontnyi zavod". Available at: http://lsarp.com.ua (accessed 20 November 2020).

4. DP "Kharkivskyi mashynobudivnyi zavod (FED)". Available at: https://fed.ua/ru/pro-pidpryyemstvo (accessed 20 November 2020).

5. PAT "Motor Sich". Available at: http://www.motorsich.com/ukr (accessed 20 November 2020).

6. Normirovanie pokazateley. Podgotovka i obrabotka, analiz i predstavlenie dannykh [Standardization of indicators. Preparation and processing, analysis and presentation of data]. Available at: https://psytest.wordpress.com/data treatment/normalization indicator (accessed 20 November 2020).

7. Yerina, A.M., \& Vashchaiev, S.S. (1999) Uzahalniuiuchi bahatovymirni pokaznyky v sotsialno-ekonomichnykh doslidzhenniakh. [Generalizing multidimensional indicators in socio-economic research]. Naukovi zapysky Kyievo-Mohylianskoi akademii. Ekonomika [Scientific notes of the Kyiv-Mohyla Academy. Economics], vol. 6, pp. 38-41.

8. Otsinka korporatyvnoho upravlinnia derzhavnym aviatsiinym sektorom Ukrainy. Pryklad DP "Antonov". OECED [Assessment of corporate governance of the state aviation sector of Ukraine Example of SE "Antonov"]. Available at: https://www.oecd.org/eurasia/ competitiveness-programme/eastern-partners/AntonovUK.pdf (accessed 20 November 2020).

9. Kovalev, V.V. (2001) Finansovyj analiz: metody i procedury [Financial analysis: methods and procedures]. Moscow: Finansy i statistika. (in Russian)

10. Higgins, R.S., \& Rajmers, M. (2007) Finansovyj analiz: instrumenty dlya prinyatiya biznes-reshenij [Financial analysis: tools for making business decisions]. Moscow: OOO «I.D. Vil'yams». (in Russian)

Tovmasian Vahan

Private Higher Educational Institution "European University"

\section{METHOD OF DETERMINING THE EFFICIENCY OF THE FINANCIAL POLICY OF THE AVIATION INDUSTRY ENTERPRISES}

The article presents the results of analysis and evaluation of the effectiveness of financial policy of enterprises based on the developed methodological approach. It is proposed to determine the effectiveness of the company's financial policy by inequality, according to which financial stability should exceed the reproducibility of financial resources, which in turn should exceed the flexibility of own investments in enterprise development, which should exceed the adequacy of financial resources for unplanned expenses. In accordance with the proposed methodological approach to assessing the effectiveness of the financial policy, its analysis was carried out by a group of surveyed enterprises of the aviation industry of Ukraine with the derivation of generalized results for the section of enterprises of the studied industry. A comprehensive assessment of the financial policy efficiency indicators of Antonov, Kyivaeroproekt LLC, Konotop Aircraft Repair Plant Aviacon, Lviv State Aircraft Repair Plant, Kharkiv Machine-Building Plant (FED) and Motor Sich PJSC was conducted. Integral indicators corresponding to the defined criteria are used, which are aimed at deviation determining of the total value of the effectiveness of regulatory and optimizing financial instruments, which will determine the level of improvement of the enterprise. A methodical approach to determining the effectiveness of financial policy based on the use of a hierarchical model of building an integrated indicator, which contains the basic indicators: indicators of the dynamics of the objects of financial policy. It is determined that in order to increase the efficiency of the financial policy of aviation enterprises, regulatory and optimization tools should be directed to the objects of financial policy, which will increase its level according to the criteria of "turnover" and "sustainability". It is found that the proposed scientific and methodological approach to assessing the economic results of the financial policy of the aviation industry, will determine its status and adjust the decision-making system, modernizing the system-forming elements of management and economic influence on innovation in the post-crisis period.

Key words: finance, financial and economic relations, financial management, criteria for evaluating financial policy, financial indicators, financial analysis.

JEL classification: E37, M20, L93 